\title{
ANALYSIS BY AHMAD DONISH ABOUT THE STATE ADMINISTRATION OF THE MANGYT RULERS
}

\section{Zebiniso Azizovna Akhmedova}

Head Of Department Of Social Sciences Bukhara State Medical Institute, Uzbekistan

\section{ABSTRACT}

In the history of Central Asian socio-political thought, Donish was one of the first to advance the idea of a connection between the origin of the state and property. According to him, the right to land ownership arises not by the will of Allah, but as a result of violence and aggression of one person over another.

Inequality, he said, has led to many conflicts. In order to establish peace in society, the land must be divided equally among the people, because "everyone is equal in the inheritance of the father, and therefore the habit of bloodshed must be abolished, so that people can live in peace and tranquility."

KEYWORDS: - Ahmad Donish, Samarkand, Emir, Minister of Military Affairs, Minister of Education, General Affairs, Ministry of Internal Affairs, Chief of Chancellery, Chief Water Distributor.

\section{INTRODUCTION}

Donish's view that "the state was created by the people by agreement between them and the rulers to protect them from thieves and robbers" is closer to the conciliation theory of the origin of the state. According to Ahmad Donish, the first duty of the state is to take care of the people. Therefore, governors have to worry about the growth of the state economy, digging canals, building reservoirs, roads, bridges, land development, processing of mineral resources, enlightening the people, developing science and technology, opening schools and special educational institutions. In this way,
Ahmad Donish showed that the duties of the state are subordinated to the public interest.

In order to establish state power, "a country must have a certain amount of troops. A king is not a king without an army, and an army cannot exist without a treasure. "Wisdom likens state power to that of a man sitting on a throne. It takes five things to see it: justice, army, people, water, treasure.

According to Donish, "the state should serve not for the needs of a group of people, but for the benefit of the people, for the prosperity of the country." "In governing the country," said Donish, "the ruler must solve important state problems together with his 
CURRENT RESEARCH JOURNAL OF PHILOLOGICAL SCIENCES 2(12):

122-129, December 2021

DOI: https://doi.org/10.37547/philological-crjps-02-12-25

ISSN 2767-3758

(C)2021 Master Journals

Crossref do

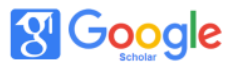

Accepted15 th December, 2021 \& Published 20 th December, 2021

advisers." This means that if the ruler relies on knowledge, experience, and justice, he will fulfill his duty fully and clearly. He substantiates this conclusion as follows:

First of all, let the Emir and other ministersgovernors agree, let there be friendship and alliance between them. Let them decide state affairs on the basis of consultative advice. The war and bloodshed in Central Asia must end. Disputes between states should be resolved peacefully, through consultation. War brings misery, destroys the country, and disturbs the people.

Secondly, a wise and just king should appoint honest, conscientious, business-minded, respectable people to the position of the state, let them abide by the rules of the state, and be a pink refuge in everything. Let them resolve issues on the basis of truth and justice. Let them consider the case of the emir at a certain time, for they may make a mistake, abuse the position. Ahmad Donish said: "The tyranny of the officials is, in fact, the tyranny of the sultan, because he himself allowed it and agreed to it."

Thirdly, in the Memoirs of Ayni, it is narrated that the sanitary condition of cities and villages in Bukhara and in Central Asia in general is very dirty. This situation has led to the emergence of various infectious diseases, increased mortality. In this regard, Donish, as a humane person, in order to improve the sanitary condition, first of all, requires the maintenance of health for the development of various fields. Health care physicians need to be strong. "If the doctor is not wise," writes Donish, "the people will be afflicted with various diseases and die."

The thinker concluded that change was necessary to improve life, to eliminate injustice, and expressed this view as a dream interpretation. His friends dream: in the dream of the first, a lion comes among the mammals and runs in all directions out of fear, but the mammals kill the lion alone; in the dream of the other, the moon appears in the sky during the day and falls to the ground like a muscle. After him, the star also falls from the sky and falls to the ground. The thinker explains the interpretation of dreams as follows: "If the kingdom in Movarounnahr is kept in the hands of this class, the next generation will see what life will be like: the rulers are ignorant, the scholars are lazy, the soldiers are ignorant. What will happen to this state of mangits and their subordinates? What does the fall of the moon and stars indicate? " Ahmad Donish makes two different points of view: in the tradition, seeing the moon at half-day is a sign of goodness, but in the interpretation of sorcerers, it is a sign of evil. It can also be said that the lion is the king of beasts, and its destruction by wild beasts (here the upper class is taken into account) is a sign of the collapse of the Bukhara state system.

Fourth, Donish sees cooperation as an important tool of public administration. Here the author is referring to the interactions between states. The author emphasizes the need to strengthen friendly relations with Russia and other countries. During his travels and as a result of his contacts, he felt that trade and cultural ties between Bukhara and other countries were not well established.

Fifth, Donish considers it necessary to dig canals and draw water in order to ensure the prosperity of the country and the well-being of the people. But in those days it was difficult to bring water to the thirsty steppes. Farmers were suffering, and every year the drought-stricken lands and gardens were also severely damaged. Since Donish himself was an engineer, he studied these shortcomings well, so he devised a project to build a canal from the Amudarya. Enlighteners Mirzo Siroj and Amir in their works, as a result of the influence of Ahmad 
CURRENT RESEARCH JOURNAL OF PHILOLOGICAL SCIENCES 2(12):

122-129, December 2021

DOI: https://doi.org/10.37547/philological-crjps-02-12-25

ISSN 2767-3758

(C)2021 Master Journals

Crossref do

gil Google

Accepted15 ${ }^{\text {th }}$ December, 2021 \& Published 20 th December, 2021

Donish, addressed these issues (Bekabad canal). The purpose of Ahmad Donish's proposals and conditions was: the prosperity of the country, the well-being of the working people. He wanted Bukhara to be like the advanced European countries. Most importantly, he dreamed of prosperity and peace.

\section{THE MAIN FINDINGS AND RESULTS}

During one of his visits to Russia, Ahmad Donish learned that Tsarist Russian officials had planned to build a railway line through the city of Bukhara. He loads most of the gifts brought to the Russian tsar on a single camel. The camel does not fit with its load through the gates of the royal residence in St. Petersburg, the Winter Palace. Ahmad Donish asks the representatives of the Russian tsar to break down the gate. The Russian tsar will not allow it. So, Donish, how much does one gate cost you, and if the railway tracks pass through Bukhara Sharif, what will happen to the historical buildings inherited from our ancestors? - addressed the Russian authorities with a question. After that, the railway tracks passed through New Bukhara (Kogon), 12 km away from Bukhara.

Ahmad Donish wrote the following request to the Emir of Bukhara Muzaffar to send to the Tsar of Russia:

1. After Samarkand joined the Russian state, Bukhara is experiencing a water shortage. The governors in Samarkand own two-thirds of the water, so send us knowledgeable people who know how to bring water from the Syrdarya or Amudarya.

2. There are a lot of fruits and vegetables in our country. Help him build a factory in Bukhara to make sweets or sugar from it.

3. On the outskirts of the cities of Movarounnahr there are many mountains, which contain minerals. So it would be beneficial for both countries if you send it from people who know the science of fossils.

4. If you help to build a weaving factory in Bukhara.

We see that these thoughts of the thinker addressed not only the Emir, but also the Russian tsar with the issue of concern for the Motherland and its future, the development of the homeland and the wellbeing of the country.

Ahmad Donish called on the rulers of his time to follow the example of the great leaders, just rulers and kings of our history. He admonished his forefathers: "If the ruler before you is a drop, be the sea, and if the ruler is a moon before you, be the sun!" He believed that following the advice he gave would ensure the prosperity of the Motherland.

Ahmad Donish, in his treatises on the transformation of the state system, cites the example of just prophets, kings. Based on Islamic ethics, the thinker argues that if injustice is allowed in governing the state, God will punish such a person in the Hereafter.

Ahmad Donish generalized the socio-political views of the peoples of the East, studied the socio-political life, state-building and legislation of Bukhara and Russia, and developed a system of his views. It reflected many state and legal issues of interest to the progressives of the time, representing the interests of the working people of Bukhara.

The great merits of Donish are that, like many of his contemporaries, he not only criticized society and the state, but went ahead of them: he promoted the ideas of the lawlessness of the Emir's power, the corruption of officials and the need to completely change this government.

Donish takes an active part in the socio-political and cultural life of the Emirate of Bukhara. This allows 
CURRENT RESEARCH JOURNAL OF PHILOLOGICAL SCIENCES 2(12):

122-129, December 2021

DOI: https://doi.org/10.37547/philological-crjps-02-12-25

ISSN 2767-3758

(C)2021 Master Journals

\section{Crossref doi) 8 Google}

Accepted15th December, 2021 \& Published 20th December, 2021

him to get acquainted with the state system, legislation, domestic and foreign policy of the khanate. In the pamphlet "Civilization and the Order of Mutual Assistance" he puts forward the idea of reforming the socio-political system of the Emirate of Bukhara. In particular, he proposed to establish a parliament consisting of representatives of various classes, to develop and discuss all laws and regulations in this assembly, and then approve them by the Emir, as well as to establish an oversight administration in all areas of the state. The wise head of state emphasizes that the following obligations must be observed: timely consideration of applications and complaints and taking measures, dismissal of victims of public violence; compliance with Sharia law, assistance to the poor and orphans; to care for the welfare of the country. In addition, the ruler must ensure the security of the country, be friendly with neighboring countries, promote trade. Another task of the ruler is to involve the able-bodied in forced labor and to provide pensions for the disabled.

Ahmad Donish says "the ruler has two ministers: one to deal with revenue and the other with expenditure." He also proposes the appointment of ministers: Minister of Military Affairs, Minister of Education, General Affairs, Ministry of Internal Affairs, Chief of Chancellery, Chief Water Distributor, and others. Accordingly, it defines their functions.

The news of the system offered by Donish is as follows:

- appointment of the Prime Minister with the consent of the people and on the advice of persons of prestige;

- -determination of specific areas of work of officials;

- accountability of officials to the ruler and control over their activities;

- Taking into account the abilities, experience, knowledge of people in the appointment;

- $\quad$-assignment of salaries to officials.

Donish's work also addresses the issue of military reform, which he says will create new armed forces of the military type of European countries. He had proposed discipline, armament, training, dress, and salary in the military. According to him, "the commander-in-chief must be brave, right-thinking, military, experienced." But Amir Muzaffar rejected these ideas. "If he had accepted the pamphlet, he would not have been able to become an emir. He understood this truth well. Donish later realized this, "said Rajabov.

For justice to prevail, the state needs to be reformed in order to have a human order. Ahmad Donish, who believed that reform should take place not only in government but also in the legislature, opposes the ideas of oppression, lawlessness, law and order in his pamphlet On the Order of Civilization and Mutual Assistance. These ideas are important in any public administration.

According to Donish, the development of the country, the peace of the people, the growth of the economy, culture depend on the strict conduct of state affairs. Therefore, he writes, "it is necessary to produce a law that regulates the head of state and officials, the order of meetings, the attitude of officials, family relations, relations with other peoples."

Of course, Donish wanted to see the image of an ideal leader, and based on that, he also defined his qualities. He dreamed that the leader would be close to the people and take a place in the hearts of the people.

Knowledge can be successful in socio-political life only if the state mechanism is regulated, "of course, there must be a law on the exercise of state power, the organization of state bodies," he said. He sought 
CURRENT RESEARCH JOURNAL OF PHILOLOGICAL SCIENCES 2(12):

122-129, December 2021

DOI: https://doi.org/10.37547/philological-crjps-02-12-25

ISSN 2767-3758

(C)2021 Master Journals

Crossref doi

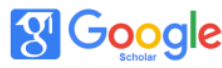

Accepted15th December, 2021 \& Published 20th December, 2021

the path of justice through enlightenment.

Ahmad Donish opposes the Emir's policy, denouncing the underdevelopment of agriculture, the salinization of fertile lands, the invasion of orchards, vineyards, crops by mobile sands, and the failure of the Emirate to take any action against it. Excessive taxes, the destruction of fertile lands, and famine and poverty as a result of the failure of irrigation systems forced them to leave their lands. Here is an example of the drying up of the Jilvon canal (now Shafirkan district), which supplies water to many areas. He stressed that this situation has a negative impact on the development of the country, the environment and public health. The thinker says that the construction of canals is mainly necessary to dig a canal from the Amudarya to Bukhara, to bring water, to study the mineral resources and use them for the development of the country. "The time will come when all the riches of the earth will be at the service of humanity. We have to overcome great difficulties for this."

Ahmad Donish was an advocate of enlightenment for all, believing that the establishment of a just government, the development of agriculture, the support of artisans, the enjoyment of scientific achievements, the training of scientists would save the Motherland and the people from backwardness. He dreamed that everyone would have a full stomach, thighs and knowledge, and at the same time be able to easily answer the questions of any foreigners who come to Bukhara.

These ideas of Ahmad Donish are of great sociomoral significance, he put forward the issues of educating young people to be enlightened, intelligent, patient, honest, pure conscience, the formation of high human qualities in them. It is expedient to recognize that the ideas of the thinker about a spiritually mature person are one of the principles of national ideology in the conditions of independence.

The works of Ahmad Donish are of great importance for the study of the socio-political history of Uzbekistan in the XIX century. In particular, the work "Biography of the Emir of Bukhara Sharif" (also called "Risola" in some sources) served as the main source for the scientist, professor A. Semyonov, who studied the history of our country. The Risola, one of the most unique works of the second half of the 19th century, consists of two parts:

1) events that the author heard and knew through written sources;

2) events that he described as a historian.

Ahmad Donish's treatise contains information that is not found in the works of other thinkers:

- $\quad$-Complete information about the Sino-Kipchak uprising;

- Extensive economic program proposed to reform the country's economy;

- The author's proposals on improving the water supply of Bukhara and its environs;

- Impressions from trips to Russia;

- Description of folk performances in the markets;

- General assessment of the Emirate of Bukhara.

The thinker was not indifferent to the conquest of Central Asia by Tsarist Russia. He pointed out the reasons for the defeat of the Emirate of Bukhara. In his view, the backwardness that prevailed in the country, the feudal limitations, the lack of even general information about the opposition army, the inexperience of military leaders, the invalidity of weapons, the economic system based on injustice accelerated the invasion.

The most noble quality in the work of Ahmad Donish is that he calls his compatriots to friendship 
CURRENT RESEARCH JOURNAL OF PHILOLOGICAL SCIENCES 2(12):

122-129, December 2021

DOI: https://doi.org/10.37547/philological-crjps-02-12-25

ISSN 2767-3758

(C2021 Master Journals

Crossref do

81 Google

Accepted15th December, 2021 \& Published 20 ${ }^{\text {th }}$ December, 2021

and cooperation with all the peoples of our country. In addition, he developed important measures for the development of the country, to bring his country and people out of backwardness: first, to establish a just government that would ensure the independence of the country; second, the development of agriculture based on the expansion of irrigation; third, comprehensive support for handicrafts; fourth, to strive for scientific achievement; fifth, it is necessary to train scientists and doctors so that the population can enjoy their services.

\section{Conclusion}

In conclusion, it can be said that the socio-political views of Ahmad Donish are of special importance in the development of the country. His ideas, which emerged in the second half of the XIX century, are still reflected today. Ahmad Donish first clarified the relationship between state and mind, state and property. Second, it defined the responsibilities of the state. Third, he raised the issue of changing the system of public administration. Fourth, it developed measures to be taken for the development of the country. Fifth, he developed the idea of a just, enlightened ruler, demonstrating his duties and responsibilities. Sixth, he expressed a positive attitude towards religious and secular sciences. Seventh, he fought for a happy and prosperous life.

\section{REFERENCES}

1. Ахмедова 3. А., Турсунов К. С. Интеграционный процесс в рамках Европейского союза //Наука, техника и образование. - 2020. - №. 5 (69). - С. 49-52.

2. Ахмедова 3. А. Астрономические взгляды Ахмада Дониш //Вестник науки и образования. - 2018. - №. 11 (47).
3. Ахмедова 3. A. HUMAN BEING IN THE WORKS OF MEDIEVAL THINKERS //Новый день в медицине. - 2020. - №. 4. - С. 115118.

4. Ахмедова 3. А. ХІХ АСРНИНГ ИККИНЧИ ЯРМИДА ТУРКИСТОН ЎЛКАСИ МАДАНИЯТИ //ВЗГЛЯД В ПРОШЛОЕ. 2021. - Т. 4. - №. 7.

5. Сагикызы А., Шуршитбай М., Ахмедова 3. UPBRINGING AND EDUCATION AS FACTORS OF HUMAN CAPITAL DEVELOPMENT //Адам әлемі. - 2021. - Т. 88. - №. 2. - С. 1825.

6. Akhmedova Z. A. THE ROLE OF TEACHING PHILOSOPHY IN MEDICAL UNIVERSITY //Наука, техника и образование. - 2021. №. 6. - C. 44-48.

7. Ахмедова 3. A. HUMAN BEING IN THE WORKS OF MEDIEVAL THINKERS //Новый день в медицине. - 2020. - №. 4. - С. 115118.

8. Azizovna A. Z. ROLE AND SIGNIFICANCE OF PHILOSOPHY IN THE LIFE OF SOCIETY //Наука, техника и образование. - 2020. №. 11 (75).

9. Ахмедова 3. А., Чориева М. А. ТРУД АХМАДА ДОНИША «ИСТОРИЯ МАНГИТСКИХ ГОСУДАРЕЙ» КАК ЦЕННЫЙ ИСТОЧНИК ПО ИСТОРИИ БУХАРСКОГО ХАНСТВА ВТОРОЙ ПОЛОВИНЫ ХVIIIПЕРВОЙ ПОЛОВИНЫ ХІХ ВВ //Наука, техника и образование. - 2020. - №. 11 (75).

10. Akhmedova Z. A. Astronomical views of Ahmad Donish //Bulletin of Science and Education. - 2018. - №. 11. - C. 47.

11. Hamdamov B. K., Temirova S. V. FROM THE HISTORY OF BUKHARA FOLK MEDICINE //CURRENT RESEARCH JOURNAL OF PHILOLOGICAL SCIENCES (2767-3758). 2021. - T. 2. - №. 12. - C. 52-55.

12. Чориева М. А. Экономика и денежное 
CURRENT RESEARCH JOURNAL OF PHILOLOGICAL SCIENCES 2(12):

122-129, December 2021

DOI: https://doi.org/10.37547/philological-crjps-02-12-25

ISSN 2767-3758

(C2021 Master Journals

Crossref d

Accepted15 ${ }^{\text {th }}$ December, 2021 \& Published 20 th December, 2021

обращение (монеты) в Бухарском эмирате при мангытах (на рубеже 19-20 веков) //Наука, техника и образование. - 2020. №. 5 (69). - С. 53-56.

13. Чориева М. А. Историография жизни и политической деятельности последнего мангытского эмира Сейида Алимхана //Наука, техника и образование. - 2018. №. 9 (50).

14. Чориева М. А. СОЦИАЛЬНОЭКОНОМИЧЕСКОЕ, ПОЛИТИЧЕСКОЕ ПОЛОЖЕНИЕ БУХАРСКОГО ЭМИРАТА В КОНЦЕ ХІХ ВЕКА //Наука, техника и образование. - 2020. - №. 11 (75).

15. Ахмедова 3. А., Чориева М. А. ТРУД АХМАДА ДОНИША «ИСТОРИЯ МАНГИТСКИХ ГОСУДАРЕЙ» КАК ЦЕННЫЙ ИСТОЧНИК ПО ИСТОРИИ БУХАРСКОГО ХАНСТВА ВТОРОЙ ПОЛОВИНЫ XVIIIПЕРВОЙ ПОЛОВИНЫ ХІХ ВВ //Наука, техника и образование. - 2020. - №. 11 (75).

16. ECONOMY C. M. A., CIRCULATION M. IN THE BUKHARA EMIRATE AT THE MANGYT (AT THE BORDER OF THE 19-20 CENTURIES) //Science, technology and education. - 2020. - №. 5. - C. 69.

17. Chorieva M. A. Historiography of the life and political activities of the last Mangyt emir, Seyid Alimkhan //Science, technology and education. - 2018.

18. MA C. EKONOMIKA I DENEZHNOYe OBRASHCHENIYe (MONETY) V BUKHARSKOM EMIRATE PRI MANGYTAKH (NA RUBEZHE 19-20 VEKOV). - 2020.

19. MA C. Istoriografiya zhizni i politicheskoy deyatel'nosti poslednego mangytskogo emira Seyida Alimkhana. - 2018.

20. Choriyeva M. A. HISTORY OF CREATION" SHAH-NAME" FIRDOUSI //CURRENT RESEARCH JOURNAL OF PHILOLOGICAL SCIENCES (2767-3758). - 2021. - T. 2. - №.
12. - C. $45-48$.

21. МА Чориева РАЗВИТИЕ БАНКОВСКОГО ДЕЛА В БУХАРСКОМ ЭМИРАТЕ (19-20 ВВ)Новый день в медицине, 2020. С. 733-735

22. Akhmedova Z. A. HEALTHY LIFESTYLE AS THE KEY TO HEALTH //SCIENCE AND WORLD. - 2013. - C. 21.

23. Ахмедова 3. А., Аннамуратов Ш. La méthodologie traditionnelle et directe d'enseignement des langues étrangères //Молодой ученый. - 2017. - №. 24-2. - С. 16-17.

24. Ахмедова 3. A. HEALTHY LIFESTYLE AS THE KEY TO HEALTH //Наука и мир. - 2018. - T. 2. - №. 4. - C. 21-22.

25. Akhmedova Z. A. THE ROLE OF TEACHING PHILOSOPHY IN MEDICAL UNIVERSITY //Наука, техника и образование. - 2021. №. 6. - C. 44-48.

26. Akhmedova Z. A. PHILOSOPHY OF THE FIRST JADID AHMAD MAHDUM DONISH //CURRENT RESEARCH JOURNAL OF PHILOLOGICAL SCIENCES (2767-3758). 2021. - T. 2. - №. 12. - C. 41-44.

27. Турсунов К. Швейцария: оценки хода государственного и общественного строительства в независимом Узбекистане //Fuqarolik jamiyati. Гражданское общество. - 2013. - Т. 10. №. 3. - С. 83-86.

28. Турсунов К. Германия: университетские исследования формирования гражданского общества в Узбекистане //Fuqarolik jamiyati. Гражданское общество. - 2009. - Т. 6. - №. 2. - С. 77-80.

29. Турсунов К. Великобритания: изучение опыта формирования основ гражданского общества в Узбекистане //Fuqarolik jamiyati. Гражданское общество. - 2011. T. 8. - №. 3. - С. 89-92.

30. Турсунов К. ЛАТВИЯ: ОЦЕНКИ РЕАЛИЗАЦИИ ГОСУДАРСТВЕННОЙ 
CURRENT RESEARCH JOURNAL OF PHILOLOGICAL SCIENCES 2(12):

122-129, December 2021

DOI: https://doi.org/10.37547/philological-crjps-02-12-25

ISSN 2767-3758

(C)2021 Master Journals

Crossref doi 81 Google

Accepted15 ${ }^{\text {th }}$ December, 2021 \& Published 20 th December, 2021

$\begin{array}{lr}\text { МОЛОДЕЖНОЙ } & \text { ПОЛИТИКИ } \\ \text { HЕЗАВИСИМОМ } & \text { УЗБЕКИСТАНЕ } \\ \text { //Fuqarolik jamiyati. } & \text { Гражданское } \\ \text { общество. - 2014. - T. 11. } & \text { - №. 1. - С. 61-64. }\end{array}$

31. Турсунов К., Бафоев $Ф$. К вопросу становления, функционирования и развития парламентской оппозиции //Fuqarolik jamiyati. Гражданское общество. - 2008. - Т. 5. - №. 1. - С. 53-58.

32. Турсунов К. БЕЛЬГИЯ: ОСВЕЩЕНИЕ ОПЫТА ФОРМИРОВАНИЯ ОСНОВ ГРАЖДАНСКОГО ОБЩЕСТВА В УЗБЕКИСТАНЕ //Fuqarolik jamiyati. Гражданское общество. - 2010. - Т. 7. - №. 2. - С. 91-94.

33. Tursunov K. S. EUROPE AND THE COMMONWEALTH OF INDEPENDENT STATES //Наука, техника и образование. 2021. - №. 6. - C. 42-44.

34. Sodikovich T. K. HISTORY OF THE BUKHARA STATE MEDICAL INSTITUTE NAMED AFTER ABU ALI IBN SINO //Наука, техника и образование. - 2020. - №. 11 (75).

35. Tursunov Q. S. NEW UZBEKISTAN AND ELECTION LEGISLATION //CURRENT RESEARCH JOURNAL OF PHILOLOGICAL SCIENCES (2767-3758). - 2021. - T. 2. - №. 12. - C. 49-51.

1. 